\title{
Natural resource reserves sustainable use and inclusive resort development
}

\author{
Kateryna Kostetska ${ }^{*}$, Nina Poyda-Nosyk ${ }^{2}$, Robert $\mathrm{Bacho}^{3}$, Vira Nevlad ${ }^{4}$, and Olena \\ Pavlenko ${ }^{5}$ \\ ${ }^{1}$ Institute of Market Problems and Economic and Ecological Research NAS of Ukraine, 29 \\ Francuzskiy bylvar, 65044, Odesa, Ukraine \\ ${ }^{2}$ Uzhhorod National University, Narodna sq., 3, 88000 Uzhhorod, Ukraine \\ ${ }^{3}$ Ferenc Rákóczi II Transcarpathian Hungarian Collage of Higher Education, Kossuth sq., 6, 90202 \\ Beregovo, Ukraine \\ ${ }^{4}$ Uman National University of Horticulture, 1 Instytutska str., 20305 Uman, Ukraine \\ ${ }^{5}$ Dnipro State Agrarian and Economics University, Serhii Efremov Str., 25, 49600, Dnipro, Ukraine
}

\begin{abstract}
The article is devoted to the directions natural resources reserves formation basis on inclusive development of the territory. We consider the definition of natural resources reserve use, which unlike common understanding reserve includes the related services provided to meet the requirements of inclusive growth. The expediency of natural resources reserves use forming is considered on the example of therapeutic muds of the Kuyalnyk estuary. Today, there is a lack of funds for infrastructure development needs for state and communal enterprises that carry out their activities on the natural resources using. Such situation has developed at the state importance Kuyalnyk resort in Ukraine. Having all the natural importance competitive advantages the implementation of health activities using the therapeutic mud of the Kuyalnyk estuary, economic activity in the area is declining due to lack of funds for infrastructure development. The problem solution is possible through the natural resources reserves formation for their further use on inclusive development base. The option principle can apply in reserves of use formation, which makes it possible to calculate the break-even point. It is also necessary to pay attention to the standards for calculating tax liabilities and their further redistribution to the needs of territorial development.
\end{abstract}

\section{Introduction}

It is an important document of today «Project of Strategy for Sustainable Development of Ukraine until 2030» of 27.12.2019, the first pillar of which is economic growth as an environmental sustainable way to create favorable business conditions. The regions of Ukraine are rich of their natural resource potential. The most important now is to achieve therapeutically people needs because of pandemic situation. Lack of inclusive accesses for people can be achieved by natural resources reserves using. For Ukraine, such a reserve is

\footnotetext{
*Corresponding author: kathryn81@ukr.net
} 
resources of the Kuyalnyk resort, which received its status in 2018 [1]. The territory of the resort has recreational and balneological potential. Of particular interest are therapeutic muds, which are characterizing as the same of the Dead Sea mud. Having significant opportunities to achieve the goals of sustainable development in the area, the lack of diversification management has led to deterioration in the quality of the recreational area and Kuyalnitsky estuary. Scientific works and program documents of the state level are devoted to the decision of this question. However, not enough attention is paid to increasing the competitiveness of the recreational area through the implementation of its resource and recreational potential. Therefore, it is advisable by therapeutic muds resources reserve of use for sale and profit, which should be further redirected to the infrastructural needs of the territory and its inclusive development. In Ukrainian legislation, environmental safety is defined in the Law of Ukraine "On environmental protection" of 25.06.1991, as the main principle that requires mandatory compliance with environmental standards, norms and rules in the use of natural resources and their maintenance in good condition. It is advisable to comply with the requirements of Le Chatelier's principle [2], as one that ensures ecosystem balance and has a positive impact on the ecosystem in the future.

Implementing natural resource reserves for use for possible excess profits through trading activity in the stock market, which in reality Ukrainian legislation exists but nominally still is only in its infancy. Experts estimate as for trading ratio volumes was about $16.6 \%$ Ukraine's GDP on the securities market in recent years. For today is more attention of participation on the stock market, trading in options on natural resource for use deserves. The advantages of such trading for the owner of natural resource for use are, first of all, risk limitation (not more than the size of the option price) and set deadlines. Achieving optimal proportions for the use of such tools is based on compliance with economic security, which according to Ukrainian legislation is measured by the following indicators: the level of capitalization of listed companies, the percentage of GDP; the level of volatility of the First Stock Trading System index, the number of critical deviations; the share of insurance premium revenues of the three largest insurance companies in the total revenue of insurance premiums (excluding life insurance), percent.

These indicators are generalized and do not provide clarity of calculations, while the existing international indices are almost not used and have no certainty in the domestic legal field. That is why the stock market is attracting more and more attention to natural resource for use as those that do not lose their value in the long run.

Purpose of the research is scientific generalization and submission of proposals for the natural resources use reserves formation on an optional basis in the context of inclusive growth.

\section{Problem statement}

Determining the natural resources reserves for the use in the framework of sustainable development and inclusive economy on the principle of option cost requires the coordination of security factors and the profitability of implementation for all stakeholders. I. Gross and J. Hansen [3] determine that reserves for each resource are measured as reserves that are considered economically viable for extraction and sub-economic reserves that do not currently exist, but they can be used in the future if prices for resources will increase or significant technological progress will take place, which will reduce the cost of their extraction. That is, temporary changes in the price resource policy can promote inclusive development through changes in investment flows and the attraction of new labor to production. J. Boyd [4] states that the formation of natural resource reserves should be based on the principle of option value, which is set to protect natural resources, even when the current benefits of natural resources use are lower than the benefits of resource 
development, degradation or conservation. This theory is based on the fact that it is extremely difficult to assess the social losses from environmental damage and the relative irreversibility of environmental losses. At the same time, the created reserve of natural resources can be used through a hedging strategy or by supporting its ecological investment portfolio for future generations. In the Reserven report [5], the authors define the reserves of natural resources as those that at today's prices and with the help of modern technologies are economically viable for production while maintaining the ability to recover. The German company SES [6] stated that the reserve indicates how much raw material is still available and can be extracted according to economically justified criteria and available technologies. P. Dasgupta [7] notes that the reserves of natural resources should be formed in the conditions of discounting and taking into account the ethical aspects of discounting, namely, the general benefits for society ("happiness") in the world should be used to the maximum.

Natural Resource Government Institute [8] determines the reserve of natural resources a special purpose investment instrument owned by the government, the main source of funding which is the income received from the sale of natural resources. At the same time, the following macroeconomic goals are achieved: savings for future generations, coverage of the budget deficit, sterilization of capital inflows, allocation of resource revenues for specific items of expenditure and define natural resource reserve for use as resources that benefit from economic activity [9]. Accounting standard [10] determines inventories assets held for resale (distribution, transfer) under normal business conditions. That is, inventories are recognized as an asset if it is probable that future economic benefits associated with their use will flow to the enterprise and their value can be measured reliably. Adherence to aspects of inclusive development of the territory is the possibility of access to each member of society to obtain aesthetic, economic, emotional benefits from natural resources in conjunction with the formation of new requirements for the regulatory framework basis on accessibility and responsibility for the environment and rational natural resources use to achieve a new quality of life [11-12].

The natural resources reserve for use is the available relevant resources and related services in the natural resource potential of the territory formed in according to quality criteria, which will be implemented in the future on the principle of option value. According to "Tax Code of Ukraine» [13] - a civil contract under which one party to the contract receives the right to purchase (sell) the underlying asset, and the other party undertakes an unconditional obligation to sell (purchase) the underlying asset in the future during the term of the option or on a specified date (date of performance) at the price of the underlying asset determined at the time of concluding such a contract. Under the terms of the option, the buyer pays the seller a premium on the option, which consists of the intrinsic value and the temporary value of the natural resource reserve for use. The law does not set the amount of the premium in relation to the assets, so it is usually $10 \%$. The option principle will maintain a balance between the qualitative characteristics of natural resources reserves and the extra profit from their withdrawal, as the option premium is not subject to VAT under the Tax Code of Ukraine and is not included in gross income as funds from securities placement. Also, unlike other market segments, stocks of natural resources have shown that they can be negatively correlated with a wider stock market over a long period [14-15].

Determining the conditions for the sale of natural resource reserves for use on the option principle value requires coordination with the requirements of economic security in the stock market of Ukraine. Methodical recommendations concerning calculation of level of economic safety of Ukraine (2013) regarding the calculation of the economic security level of Ukraine, it is determined that the economic security of the non-banking financial sector (which includes the stock market) is such a level of its development that allows to fully 
meet the needs of society in these financial instruments and services [16-18]. The indicators used to assess the level of economic security in the stock market in Ukraine include: the level of capitalization of listed companies, the percentage of GDP; the level of volatility of the index of the First Stock Trading System, the number of critical deviations (-10 percent); the share of insurance premiums of the three largest insurance companies in the total income of insurance premiums (excluding life insurance), percent.

Company Market Track (2019) the Stock Market Security Index (MSI) is proposed as the difference between the SP500's extrapolated yield and the current 90-day TBILL interest rate. The extrapolation is 13 weeks and is calculated by the limited square of the least squares for the previous 52 weeks of earnings. A value of MSI above zero means that the return on shares exceeds the return on TBILL and the market is undervalued [19].

Another stock market security index founded by CNN Money [14] is the Fear and Greed Index, which includes 7 indicators: stock price momentum: S\&P 500 compared to its 125-day average, stock price strength: the number of shares that reached 52-week highs and lows on the New York Stock Exchange; range of stock prices: the volume of stocks traded on the rise, compared with those that are declining; Put and Call options: a put / call ratio that compares bullish call trading volume to bearish put trading volume; Demand for Bond bonds: the difference between the yield of investment-grade bonds and issuance bonds; market volatility; Haven Demand: the difference in yields on stocks and treasury bonds.

When considering the economic security of the stock market, it should be emphasized that there are many definitions of parameters for calculating its security, and the legal framework in different countries is controversial, especially with regard to trading options on natural resources, such as those whose quality depends on environmental security of natural resource potential. Since we are talking about option contracts in the stock market, and the subject of the option are natural mineral resources, such activities pass all levels of state control both in the extraction of mineral resources and their subsequent implementation.

\section{Material and methods}

In order to determine the theoretical basis of the study, the methods of scientific abstraction and generalization were used. Methodological approaches to defining the concept and essential content of the reserve for the use of natural resources were analyzed.

The Black - Scholes Option Pricing Model, the CALL option premium, was used to justify the feasibility of creating reserves for the use of natural resources for use on the example of therapeutic muds of the Kuyalnytsya estuary and future profits by both the reserve owner and the recipient. According to the calculations, the "fair" premium for the European CALL-option RPA / USD amounted to \$ 5211,785 per contract. However, the study was conducted assuming that the Stock Market of Ukraine has all the properties inherent in such trading in fact, which today causes some contradictions related to the imperfect legal framework and information and communication support. Therefore, the calculations were made to meet the needs of economic activity in the territory of Kuyalnyk.

\section{Results and Discussion}

\subsection{The scheme of natural resources reserve of use formation}

In an inclusive and secure environment, the well-being of the population is one of the primary factors, as it determines such important social developmental characteristics as public health and education. 
Data from the European Bank for Reconstruction and Development prove that the decline in the main economic indicators of the country's development is due to the exclusion of environmental factors.

Thus, according to the WHO, from $0.2 \%$ to $0.5 \%$ of the world's population dies annually from infections of the lower respiratory tract, and 96 people per 100,000 from environmental pollution, which proves the high impact of environmental safety on the welfare of the population. All this has led to the justification of the feasibility of forming reserves for the use of natural resource in the framework of sustainable and inclusive development [25-27]. The scheme of natural resource reserve for use formation is shown in Fig. 1.

For a clearer example of the natural resource reserve for use formation will be considered on the example of the clinical sanatorium Pirogov with the use of therapeutic mud Kuyalnitsky estuary of Odesa region.

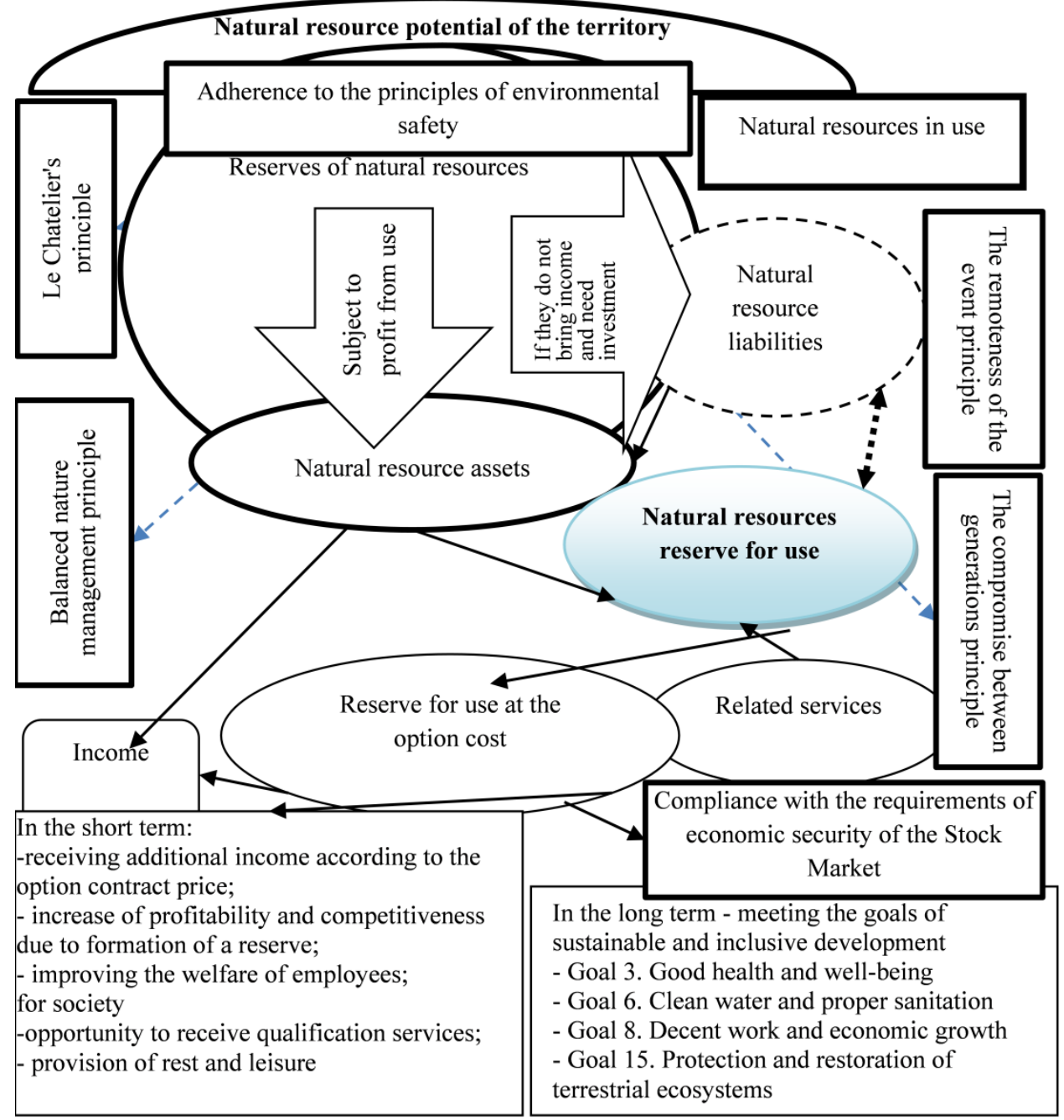

Fig. 1. The scheme of natural resource reserve for use formation is shown. 


\subsection{Ecological and economic characteristics of the Kuyalnyk resort territory}

Kuyalnyk resort is located in the south of Ukraine, in Odesa region and is characterized by high natural and recreational potential. Almost fifty percent of all recreational lands in Odesa region are located in Odesa $-22.10 \%$ and Kominternovsky district $-24.36 \%$. Among others - the city of Belgorod-Dniester $-12.55 \%$ and Ovidiopol district $-10.17 \%$. Based on the fact that Art. 88 Water Code of Ukraine (1995) states: "coastal protection strips are established for individual land management projects", and the land management project of Kuyalnyk resort does not yet exist, then according to current legislation, in particular Article 88 of the Water Code, coastal protection strip along seas and estuaries water protection zone and is not less than $2 \mathrm{~km}$, and Article 58 p.1.b and Article 59 p.4 Land Code of Ukraine (2001) refers to the coastal protection strips to the lands of the water fund, which can be transferred only on lease for haymaking, fishery needs, cultural and recreational, recreational, sports and tourism purposes, research. Owners or tenants conduct agricultural activities in the protected areas of the Kuyalnitsky estuary, which contradicts the norms of the legislation. Thus, based on cadastral data, on the territory of Kominternivsky, Bilyaivsky and Lymansky districts, on an area of more than 3000 hectares, agricultural entities operate on lease, and on an area of more than 3520 hectares, landowners for agricultural activities. On the rights of sublease of communal property on 2.4 hectares the enterprise of a high degree of risk on production of the concrete solutions ready for use [30].

Obtained to the results prove today there is a complete disregard for the legislation on economic activity within the coastal protection zone of Kuyalnitsky estuary, which causes a heavy load on the natural resource potential of the territory and affects its quality characteristics for the formation of reserves of natural resources neglects the principles of environmental safety.

The legislation of Ukraine stipulates that mineral resources are recognized after obtaining the legal right to conduct exploration work. The information obtained during the exploration and evaluation of mineral resources, as well as during the development of deposits, is a clarification of the value of assets related to exploration. Mineral resources are measured at cost, with the financial statements additionally disclosing information about the volume and current value of reserves [31-33].

According to Art. 12 of the second part, Art. 14 of the first part of the Economic Code of Ukraine (2003) one of the main means of regulatory influence of the state on the activities of economic entities is licensing, aimed at ensuring a unified state policy and protection of economic and social interests of the state and society. The procedure for granting special permits for subsoil use determines that the fee for granting a special permit for subsoil use, namely for the extraction of minerals by existing enterprises is 60 tax-free minimum incomes. It is established by point 5 of subsection 1 of section $\mathrm{XX}$ of the Tax code of Ukraine the sum is equal to $17 \mathrm{UAH}$. That is, to obtain a license for a period of 20 years (for the extraction of minerals) in 2020 will cost the company only 1020 UAH [13, 22-23]. At the same time, the Tax Code of Ukraine provides formulas for self-calculation of rent for the extraction of minerals. Thus, in our opinion, the gap in the legal framework and control regime does not allow the development of options trading.

\subsection{Approbation of the possibility of natural resources for use reserves forming at option cost}

Conclusions of the Physico-Chemical Institute for Environmental and Human Protection of the Ministry of Education and Science of the National Academy of Sciences and the National Academy of Sciences of Ukraine, including 15 million cubic meters of particularly 
valuable black mules, valued at about $\$ 7$ billion. USA [31]. The chemical composition of the therapeutic muds of the Kuyalnitsky estuary in terms of chloride, potassium, sodium, magnesium and calcium is almost equal to the muds of the Dead Sea (Fig. 2). Another important aspect is that after use, the therapeutic mud is cleaned and returned to the estuary for further regeneration and possible extraction in the future.

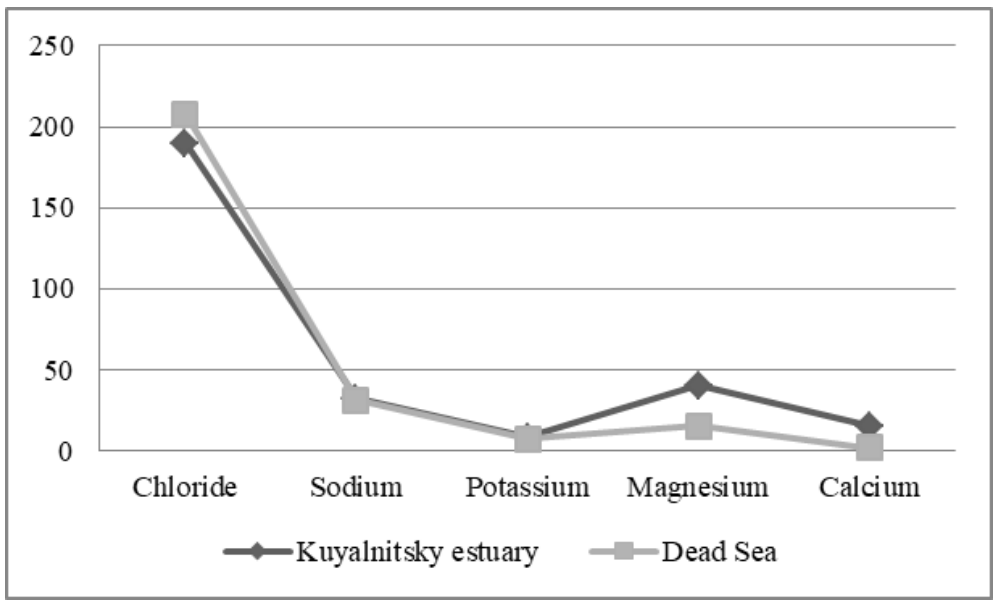

Fig. 2. Chemical composition of Kuyalnitsky estuary VS Dead Sea mud

Also, some comparisons of the use of therapeutic mud of the Kuyalnitsky estuary and the Dead Sea are given in Table 1.

Table 1. Some comparisons of the use of therapeutic mud of the Kuyalnitsky estuary and the Dead Sea.

\begin{tabular}{|c|c|c|c|}
\hline $\begin{array}{l}\text { The name of the } \\
\text { procedure }\end{array}$ & Pirogova Sanatorium & Nemo Spa & Dead Sea Spa \\
\hline Mud wraps & $20 \mathrm{~min}-200 \mathrm{UAH}$ & $\begin{array}{c}40 \min -700 \\
\text { UAH }\end{array}$ & $\begin{array}{l}40 \min -1185 \\
\text { UAH }\end{array}$ \\
\hline Local mud applications & 20 min - $200 \mathrm{UAH}$ & $\begin{array}{l}40 \min -500 \\
\text { UAH }\end{array}$ & $\begin{array}{c}30 \text { minutes - } 851 \\
\text { UAH }\end{array}$ \\
\hline Bath & $20 \min -250 \mathrm{UAH}$ & $\begin{array}{c}20 \min -800 \\
\text { UAH }\end{array}$ & $\begin{array}{c}50 \text { min }-1332 \\
\text { UAH }\end{array}$ \\
\hline Balneology for the feet & $20 \mathrm{~min}-140 \mathrm{UAH}$ & $\begin{array}{c}40 \min -900 \\
\text { UAH }\end{array}$ & \\
\hline Body care & & $\begin{array}{c}60 \text { min }-1200 \\
\text { UAH }\end{array}$ & $\begin{array}{c}70 \text { min }-2183 \\
\text { UAH }\end{array}$ \\
\hline $\begin{array}{c}\text { The average cost of the } \\
\text { service }\end{array}$ & $198 \mathrm{UAH}$ & $820 \mathrm{UAH}$ & $1388 \mathrm{UAH}$ \\
\hline Price for a stay of 14 days & $12000 \mathrm{UAH} /$ person & $\begin{array}{c}85400 \mathrm{UAH} / \\
\text { person }\end{array}$ & $\begin{array}{l}28000 \mathrm{UAH} / \\
\text { person }\end{array}$ \\
\hline
\end{tabular}

It can be argued that having all the advantages in providing treatment and related services at a lower price, the clinical sanatorium. Pirogov is not in demand. This is also evidenced by the indicators for the extraction of therapeutic mud for the period from 2013 and the plan for 2020 (Geoinform website): 1,171; 2,045; 1.82; 2,165; 1,368; 3,237; 2,823; 2,700 [1]. From the above data we state that the mud of the Kuyalnitsky estuary meets the principles of environmental safety and can be formed in the reserve for the use of natural resources. 
Assuming that the requirements of economic security of the stock market are met, it is advisable to consider how the reserve will be implemented on the principle of option value and calculate the premium of the option. The expediency of entering the stock market is due to the low price for its implementation. National Securities and Stock Market Comission (2020) provides for the conduct of activities on the basis of certification, the issuance of a certificate for the right to carry out actions related to the direct conduct of professional activities in the stock market is carried out within 30 days from the date of application and the document is issued for 1 month. The service costs UAH 450, so the right to operate in the stock market will cost UAH 5.400 / year.

All the necessary data for the calculations were extracted from the Environmental Impact Assessment Report for the extraction of minerals of the State Enterprise "Clinical Sanatorium named after Pirogov" [32]. According to the Protocol № 2 from 21.12.2019 of joint consideration of the project of the plan of development of mining works for 2020 on the Kuyalnitsky field of medical muds of "Clinical Sanatorium named after Pirogov ", as part of the representatives of the Main Department of the State Labor in Odesa region, for 2020, the company plans to extract therapeutic mud $2700 \mathrm{~m}^{3}$.

According to GVNP "Geoinform of Ukraine" stocks as of 01.01.2013 amount to 187.6 thousand $\mathrm{m} 2$ [32]. The main indicators of the sanatorium "Kuyalnyk": 300 working days a year, up to 450 employees, up to 1500 vacationers. Mud Hospital of the State Enterprise "Clinical Sanatorium named after Pirogov" consists of 3 mud compartments with a total capacity of 39 couches. The number of treatment sites by type of procedure is: $35 \mathrm{~kg}$ (39 couches, 21 showers); $0.5 \mathrm{~kg}$ (12 couches); $50 \mathrm{~kg}$ (7 baths); $0.3 \mathrm{~kg}$. We calculate the total number of natural resource assets, assuming that, as stated in the environmental impact assessment report (2019), the total number of visitors is 1,500 people. for 300 days. Given the full load, namely the need for $85.5 \mathrm{~kg}$ of therapeutic mud for 79 procedures, at a density of $1.4 \mathrm{~kg} / \mathrm{m} 3$, the norms of therapeutic mud, which is 1 time in 3 days and a course of treatment in 14 days ( 5 procedures), the reserve of natural resource assets excluding related services should be $5682 \mathrm{~m} 3$ (Table 2). Based on the data in Table 2, the average cost of 1 procedure is equal to UAH 198, which includes the cost of mud. Given that 79 procedures are $59.85 \mathrm{~m} 3$ of mud, it is not difficult to calculate that the cost of providing services should be equal to 42722 dollars, and natural resources in the reserve are 1671473.94 dollars. The reserve itself is equal to 1714195.94 dollars.

Table 2. Estimated data.

\begin{tabular}{|c|c|c|c|c|c|c|}
\hline $\begin{array}{c}\text { Cost of } \\
\text { medical } \\
\text { mud stocks }\end{array}$ & $\begin{array}{c}\text { Volume } \\
\text { of stocks }\end{array}$ & $\begin{array}{c}\text { Amount } \\
\text { per }^{3}\end{array}$ & $\begin{array}{c}\text { Will be } \\
\text { extracted }\end{array}$ & $\begin{array}{c}\text { Natural } \\
\text { resource } \\
\text { for use }\end{array}$ & $\begin{array}{c}\text { Reserve of } \\
\text { natural } \\
\text { resource for } \\
\text { use }\end{array}$ & $\begin{array}{c}\text { Cost of } \\
\text { services } \\
\text { provision }\end{array}$ \\
\hline $\begin{array}{c}7000 \\
\text { million } \\
\text { dollars }\end{array}$ & $\begin{array}{c}23.8 \\
\mathrm{mln} \cdot \mathrm{m}^{3}\end{array}$ & $\begin{array}{c}294.17 \\
\text { dollars } 1 \\
\mathrm{~m}^{3}\end{array}$ & $2700 \mathrm{~m}^{3}$ & $\begin{array}{c}794259 \\
\text { dollars }\end{array}$ & $\begin{array}{c}5682 \mathrm{~m}^{3} \\
1671473.94 \\
\text { dollars }\end{array}$ & $\begin{array}{c}42722 \\
\text { dollars }\end{array}$ \\
\hline
\end{tabular}

For calculations, we have chosen the formation of one reserve based on the documents on the extraction of mud for 2020.

According to our assumption that the reserve of natural resource assets should be sold at option value, we will use the Black-Scholes formula. Preparation of data for calculations was carried out with the help of Excel and recommendations for their calculation. The value range of our reference (vanilla) natural resource reserve for use / USD (Fig. 3). A series characterized by the characteristics of the lognormal distribution with a standard deviation equal to $0.005(0.5 \%)$. 


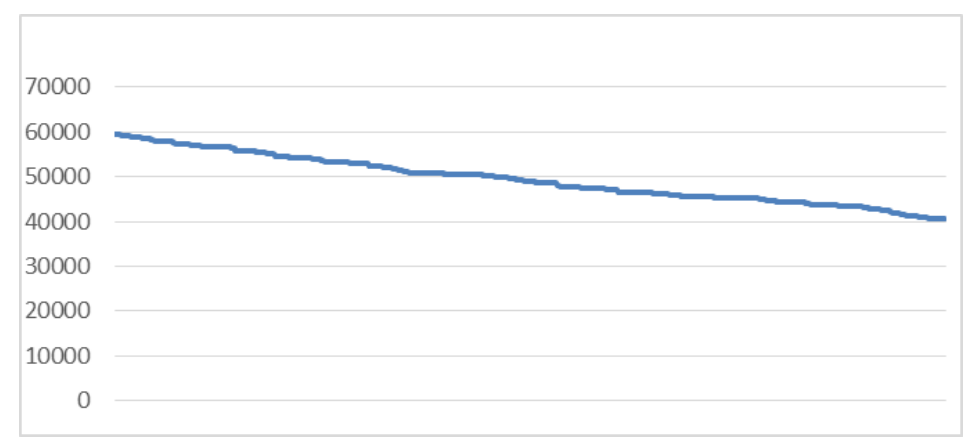

Fig. 3. Natural resource reserve for use / USD.

According to the data obtained, natural resource reserve for use tend to decrease in time.

Conditions for calculation: The price $(S)$ is equal to 1714195.94 dollars. Strike $(X)$ is equal to 1714195.94 dollars. Expiration after 300 days (T). Volume - one contract. Therefore, according to the formula of the European Call option, we will calculate whether it is profitable to create a reserve and what will be the premium of option $(C)$ (formulas 14):

$$
\begin{aligned}
& C=S N\left(d_{1}\right)-X e^{-r T} N\left(d_{2}\right) \\
& d_{1}=\frac{\ln \left(\frac{S}{X}\right)+r\left(r+\frac{\delta^{2}}{2}\right) T}{\delta \sqrt{T}} \\
& d_{2}=d_{1}-\delta \sqrt{T}
\end{aligned}
$$

$S$ current (1714195.94 USD) and X strike (1714195.94 USD) value of natural resource assets. $T$ - time to expiration, expressed as part of the year. For example, our natural resource assets contract is traded 300 days a year. Expiration will occur in 30 days, therefore, $\mathrm{T}=30 / 300 \sim 0.1$. $r$ - without risk interest rate, equal to $0 . \sigma$ (sigma) - historical volatility of the asset. For volatility, we take the standard deviation (RMS), listed at an interval of 300 days.

$$
S o=\sqrt{\frac{1}{n-1} \sum_{i=1}^{n}\left(x_{i}-\bar{x}^{2}\right)}
$$

An extract from the calculations of the required data for the Black-Scholes model is given in Table 3.

Table 3. Extract from the calculations of the required data for the Black-Scholes model.

\begin{tabular}{|c|c|c|c|c|c|}
\hline & Inv CDF & Random & $\Delta$ & $\begin{array}{c}\text { Natural resource } \\
\text { reserve for use } \\
\text { /USD }\end{array}$ & D, \% \\
\hline 0.001 & -0.01545 & 850 & 0 & 1714196 & \\
\hline 0.002 & -0.01439 & 288 & 0 & 1714196 & 0 \\
\hline 0.003 & -0.01374 & 406 & 0 & 1714196 & 0 \\
\hline $\mathrm{P}$ & Avg D, \% & $(\mathrm{D}-\mathrm{AvgD})^{\wedge 2}$ & $\mathrm{~S}$ & $\sigma$ & $\sigma$ \\
\hline 0.001 & -0.03308 & & 0.015958 & 0.126326 & 0.121912 \\
\hline 0.002 & & 0 & & & \\
\hline 0.003 & & 0 & & & \\
\hline
\end{tabular}


It remains to list the value of SLE $(\sigma)$ at intervals of 300 days. Our natural resource reserve / USD is traded 300 days a year. The value of $\sigma$, calculated for one day, must be multiplied by the square root of 300 :

$$
\sigma_{Y}=\sigma \sqrt{300}=0.1392 \% * 17.32=2.41 \%
$$

Knowing all the necessary values for the Black-Scholes model, we perform calculations (Table 4).

Table 4. Calculation of the premium on the option CALL.

\begin{tabular}{|c|c|c|c|c|c|c|c|}
\hline 1714196 & $\mathrm{~S}$ & price & $\mathrm{d} 1$ & 0.003811 & & $\mathrm{~N}(\mathrm{~d} 1)$ & 0.50152 \\
\hline 1714196 & $\mathrm{X}$ & strike & $\mathrm{d} 2$ & -0.00381 & & $\mathrm{~N}(\mathrm{~d} 2)$ & 0.49848 \\
\hline 0.1 & $\mathrm{~T}$ & $\begin{array}{c}\text { term, part of } \\
\text { the year }\end{array}$ & & & & $\mathrm{N}(-\mathrm{d} 1)$ & 0.5 \\
\hline 0.0241 & $\sigma$ & $\begin{array}{c}\text { annualized } \\
\text { volatility }\end{array}$ & & & & $\mathrm{N}(-\mathrm{d} 2)$ & 0.5 \\
\hline 0 & $\mathrm{r}$ & risk free rate & & & & & \\
\hline & & & & & CALL & 5211.785 & \\
\hline
\end{tabular}

The "fair" premium for the European CALL-option of natural resource reserve / USD with a strike of 1714196 and expiration in 30 days amounted to $\$ 5211.785$ per contract.

The natural resources reserves formation of within the framework of sustainable and inclusive development on the example of therapeutic muds of Kuyalnitsky estuary and the feasibility of their implementation on the principle of option cost was justified given the compliance with the principles of environmental and economic safety.

A problematic aspect is the redistribution of profits from the sale of reserves of natural resources to the infrastructure of the resort Kuyalnyk. Fundamentally important is the redistribution of profits and taxes from economic activities for the restoration of recreational resources at the regional level. It is necessary to prescribe methodological explanations on tax obligations and benefits to enterprises involved in this process, given the status of the territory in which the process of recreation, taking into account the therapeutic characteristics of the territory and extraction of natural resources in this area. Almost all tax liabilities from the use of medical resources go to the state budget, and have to the local with their subsequent provision to entities that use them in their activities in the form of benefits to improve the ecological situation of the recreational and tourist area [3338].

\section{Conclusions}

The study proves that in the conditions of inclusive development the state has all the initial data for the natural resource reserves formation based on the principles of environmental safety, as those that will ensure sustainable and inclusive development of the territory.

Ensuring the economically safe functioning of the stock market of Ukraine remains an unresolved part of the issue. The legislative basis is fully created. However, in everyday practice there are contradictions concerning the imperfection of the infrastructure, the problems of entering the market of foreign partners, corruption and underdeveloped information and communication system. The solution to this issue is to decentralize the powers of local authorities to control the quality of natural resource assets and regulate the information and communication field of regional players in the stock market of Ukraine. It is also necessary to pay attention to the standards for calculating tax liabilities and their further redistribution to the needs of territorial development. Today, almost all taxes go to 
the state budget, and the needs of infrastructure development must be provided from the local. In our opinion, the recommendations for the implementation of such a process should be fully agreed upon when making management decisions for areas of special natural status, such as the resort of Kuyalnyk.

To test the feasibility of forming a reserve for the use of natural resource assets, we selected the territory of the Kuyalnitsky estuary in Odesa region, which is suitable for this according to the qualitative characteristics of environmental criteria, and made calculations to receive the Call option premium. Execution of option trades on the stock market on the basis of its safe economic functioning, in order to obtain a profit from the sale of natural resources, which should be further redistributed to the infrastructure of the territory meets the principles of sustainable and inclusive development as such in the future natural resource reserve.

The article proves that the reserves formation must be carried out on the principle of option value, because for the owner of the reserve is a double benefit. First, it is the premium from the sale of the right to purchase the reserve and, secondly, the sale price of the reserve will not decrease, despite the fact that the price of natural resources will decrease in the short term. In our specific example, this would make it possible to improve the infrastructure and services for greater competitiveness of the Kuyalnyk resort area. As noted in this study, having the necessary resources and conditions for the implementation of SPA sanatorium is not in demand. While the spa center at the hotel NEMO, in Odesa, using the same therapeutic mud, is in great demand, despite their prices. This situation is caused by the fact that there is no diversification in the activities of state and communal property entities, as a result, there is a lack of financial infusions for the development of recreational areas of state importance.

According to the calculations, the "fair" premium for the European CALL-option of the reserve of natural resources / USD amounted to $\$ 5211,785$ per contract. However, the study was conducted assuming that the stock market of Ukraine meets all the requirements of economic security, which today causes some contradictions related to the imperfect legal framework and information and communication support. Therefore, we consider it necessary to further consider the decentralization of powers to control operational activities and create conditions for the involvement of foreign partners.

The article has been written in connection with the research work Inclusiveness of the economy of impressions in the nature management. "State registration No. 0119U000229".

\section{References}

1. Verkhovna Rada of Ukraine (2018). Law of Ukraine On declaring the natural territories of the Kuyalnytsya estuary of the Odessa region a resort of state importance https://zakon.rada.gov.ua/laws/show/2637-19\#Text

2. Kenneth, H. (2010). Le Chatelier's Principle in Sensation and Perception: Fractal-Like Enfolding at Different Scales. Front Physiol, 1(17). https://doi.org/10.3389/fphys.2010.00017

3. Gross I., Hansen J. (2013). Reserves of Natural Resources in a Small Open Economy. Reserve Bank of Australia.

4. Boyd J., \& Spencer B. (2006). What are Ecosystem Services? Ecological Economics, 63(2-3), 616-26. URL: https://media.rff.org/documents/RFF-DP-06-02.pdf

5. Gray C., Slade E., Mann D., Lewis O. (2014). Do riparian reserves support dung beetle biodiversity and ecosystem services in oil palm-dominated tropical landscapes? Basic and Applied Ecology, 8(15), 693-700. https://doi.org/10.1016/j.baae.2014.09.009 
6. Taylor D. (2014). ICANN offers rapid relief to trade mark holders in clear cases of infringement. Journal of Intellectual Property Law \& Practice, 9(5), 357, https://doi.org/10.1093/jiplp/jpu038

7. Dasgupta P. (1999). Climate change, intergenerational equity and the social discount rate. PR Portney and JP Weyant, ed., Discounting and Megegeneraity Equity. Washington DC: Resources for the Future.

8. Natural Resource Government Institute (n.d.). https://resourcegovernance.org/naturalresource-funds

9. Shevchenko H., Petrushenko M., Burkynskyi B., Khumarova N., \& Kodzhebash A. (2021). Input-output analysis of recreational assets within the inclusive sustainable development in Ukraine. Entrepreneurship and Sustainability Issues, 8(3), 90-109. https://doi.org/10.9770 / jesi.2021.8.3 (5)

10. Verkhovna Rada of Ukraine (1999). Accounting regulations (standards). https://zakon.rada.gov.ua/laws/show/z0751-99

11. Kostetska, K., Khumarova, N., Umanska, Y., Shmygol, N., \& Koval, V. (2020). Institutional qualities of inclusive environmental management in sustainable economic development. Management Systems in Production Engineering, 28 (2), 15-22. https://doi.org/10.2478/mspe-2020-0003

12. Kostetska, K., Laurinaitis, M., Savenko, I., Sedikova, I., \& Sylenko, S. (2020). Mining management based on inclusive economic approach. E3S Web Conference, 201, 01009. https://doi.org/10.1051/e3sconf/202020101009

13. Verkhovna Rada of Ukraine (2011). Tax Code of Ukraine. https://zakon.rada.gov.ua/laws/show/2755-17

14. CNN Money (2020). Fear and Greed Index. https://money.cnn.com/investing/aboutfear-greed-tool/index.html

15. Audretsch, D.B., \& Feldman, M. (1996). Innovative Clusters and the Industry Life Cycle. Review of Industrial Organization, 11 (2), 253-273. http://dx.doi.org/10.1007/BF00157670

16. Pavelkova, D., Jircikova, E., Knapkova, A., Bialic-Davendra, M., \& Saha, N. (2011). Empirical Evidence of Development of Plastic Clusters. In B. Katalinic (Ed.), DAAAM International Scientific Book 2011 (pp. 619 - 637). Vienna (Austria): DAAAM International. https://doi.org/10.2507/daaam.scibook.2011.50

17. Tretyakova, V., Harabara, V., \& Greshko R. (2020). The stock market of Ukraine: features of functioning in modern conditions. Economy and State, 5, 103-107. https://doi.10.32702/2306-6806.2020.5.103

18. Damodaran, A. (2016). Valuing a Natural Resource Option. Eloquens, ELQ-44873-1. https://www.eloquens.com/tool/VD0IY9/finance/corporate-finance/valuing-a-naturalresource-option

19. Ceresna, P. (2018). Perspective on Trading Options on Natural Resource Companies. Option Matters, 27(1). https://www.optionmatters.ca/perspective-on-the-volatility-oncannabis-stocks

20. Tourinho, O. (1979). The option value of reserves of natural resources. Technical Report. Working paper, 94. https://doi.10.13140/2.1.3769.2488

21. Mabey, N., \& McNally, R. (1999). Foreign Direct Investment and the Environment: From Pollution Havens to Sustainable Development. WWF-UK: FDI and the Environment.

22. Shevchenko, H., Petrushenko, M., Burkynskyi, B., Khumarova, N., \& Opanasiuk, Y. (2020). Management of wellness and recreation in urban agglomerations. Problems and $\begin{array}{llll}\text { Perspectives in } \quad \text { Management, } & \text { 231-241. }\end{array}$ https://doi.org/10.21511/ppm.18(1).2020.20 
23. Kostetska, K., \& Gordiychuk, J. (2019). Milestones of inclusive growth as prerequisites for the formation of the experiance economy. Economy: the realities of time. Economics: time realities, 6 (46), 113-118. https://doi.org/10.5281/zenodo.3878538

24. Verkhovna Rada of Ukraine (2019). Law of Ukraine About the Goals of sustainable development of Ukraine for the period up to 2030. https://zakon.rada.gov.ua/laws/show/722/2019\#Text

25. Arsawan, I.W.E., Koval, V., Rajiani, I., Rustiarini, N.W., Supartha, W.G. and Suryantini, N.P.S. (2020). Leveraging knowledge sharing and innovation culture into SMEs sustainable competitive advantage. International Journal of Productivity and Performance Management, (in press). https://doi.org/10.1108/IJPPM-04-2020-0192

26. Koval, V., Mikhno, I., Hajduga, G. \& Gaska, K. (2019). Economic efficiency of biogas generation from food product waste. E3S Web Conference, 100, 00039. https://doi.org/10.1051/e3sconf/201910000039

27. National Securities and Stock Market Comission (2020). https://www.nssmc.gov.ua/en/

28. Market Track (2019). https://www.markettrak.com/index.html

29. Cadastral maps (n.d.). https://map.land.gov.ua

30. EOPORTAL OF URBAN THE Cadastre (n.d.). http://map.gradportal.od.ua/index.php?layer=Gran $r$

31. Physical-chemical institute for environment and human protection of MES of Ukraine and NAS of UKRAINE (n.d.). Dynamics of degradation processes of Kuyalnyk estuary. http://www.pchip.gov.ua/monitlab.html

32. Unified register for environmental impact assessment (2020). Environmental Impact Assessment Report for the Extraction of Minerals of the State Enterprise «Clinical Sanatorium named after Pirogov». http:/eia.menr.gov.ua/uploads/documents/4734/reports/s6gKYlvULS.pdf

33. Koval, V., Mikhno, I., Trokhymets, O., Kustrich, L., Vdovenko, N. (2020). Modeling the interaction between environment and the economy considering the impact on $\begin{array}{lllll}\text { ecosystem. } & \text { E3S Web }\end{array}$ https://doi.org/10.1051/e3sconf/202016613002

34. Dankeieva, O., Solomianiuk, N., Strashynska, L., Fiedotova, N., Soloviova, Y., \& Koval, V. (2021). Application of Cognitive Modelling for Operation Improvement of Retail Chain Management System. TEM Journal, 10(1), 358-367. https://doi.org/10.18421/TEM101-45

35. Kvasha, S., Pankratova, L., Koval, V., \& Tamošiūnienė, R. (2019). Illicit financial flows in export operations with agricultural products. Intelellectual Economics, 13(2), 195-209.

36. Mykytenko, V.V. (2019). System-ordered combination of value-oriented dominants of the formation of natural and economic space. Economics of nature and sustainable development, 6(25), 37-43.

37. Hutsaliuk, O., Koval, V., Tsimoshynska, O., Koval, M., Skyba, H. (2020). Risk Management of Forming Enterprises Integration Corporate Strategy. TEM Journal, 9(4), 1514-1523. https://doi.org/10.18421/TEM94-26

38. Mikhno, I., Koval, V., Shvets, G., Garmatiuk, O., \& Tamošiūnienė, R. (2021). Green Economy in Sustainable Development and Improvement of Resource Efficiency. Central European Business Review, 10(1), 99-113. https://doi.org/1010.18267/j.cebr.252 